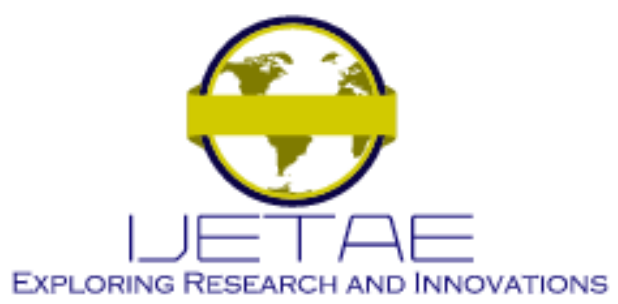

International Journal of Emerging Technology and Advanced Engineering

Website: www.ijetae.com (E-ISSN 2250-2459, Scopus Indexed, ISO 9001:2008 Certified Journal, Volume 12, Issue 01, January 2022)

Manuscript Received: 01 December 2021, Received in Revised form: 04 January 2022, Accepted: 10 January 2022

DOI: 10.46338/ijetae0122_07

\title{
Prediction of Local Government Revenue using Data Mining Method
}

\author{
Muhammad Zuhri Infusi ${ }^{1}$, Gede Putra Kusuma ${ }^{2}$, Dewi Annizah Arham ${ }^{3}$ \\ ${ }^{1,2,3}$ Computer Science Department, BINUS Graduate Program - Master of Computer Science, Bina Nusantara University, \\ Jakarta, Indonesia 11480
}

\begin{abstract}
Local Government Revenue or commonly abbreviated as PAD is part of regional income which is a source of regional financing used to finance the running of government in a regional government. Each local government must plan Local Government Revenue for the coming year so that a forecasting method is needed to determine the Local Government Revenue value for the coming year. This study discusses several methods for predicting Local Government Revenue by using data on the realization of Local Government Revenue in the previous years. This study proposes three methods for forecasting local Government revenue. The three methods used in this research are Multiple Linear Regression, Artificial Neural Network, and Deep Learning. In this study, the data used is Local Revenue data from 2010 to 2020 . The research was conducted using RapidMiner software and the CRISP-DM framework. The tests carried out showed an RMSE value of 97 billion when using the Multiple Linear Regression method and $R^{2}$ of 0,942 , the ANN method shows an RMSE value of 135 billion and $R^{2}$ of 0.911 , and the Deep Learning method shows the RMSE value of 104 billion and $R^{2}$ of 0.846 . This study shows that for the prediction of Local Government Revenue, the Multiple Linear Regression method is better than the ANN or Deep Learning method.
\end{abstract}

Keywords - Local Government Revenue, Multiple Linear Regression, Artificial Neural Network, Deep Learning, Coefficient of Determination.

\section{INTRODUCTION}

Local Government Revenue is one of the potential sources of income that is utilized by local governments as a source of financing in running the wheels of government. Based on the Law of the Republic of Indonesia No. 32 of 2004 concerning Regional Government. The authority is given to the Regional Government to regulate and manage the affairs of the government itself while still prioritizing the principles of autonomy and administration aimed at accelerating the achievement of community welfare in the region and improving services to the community, community empowerment, and community participation.
Local governments have the authority to manage their own revenues, expenditures and funding and formulate strategic policies for the progress of their respective regions. The authority of the Regional Government in managing Local Government Revenue (PAD) is expected to facilitate government affairs, development, and community empowerment in the area.

Based on Indonesian Law no. 33 of 2014 concerning Financial Balance between Central and Regional Government Article 285 letter (a) "Local Government Revenue is all regional revenue that comes from regional economic sources". This income comes from four types of income, such as local taxes, local levies, separate wealth management, and other legal income. The increasing contribution of Local Government Revenue to regional revenue has become a trigger for related agencies to continue to optimize the management of regional revenue sources from each sector. The main key to the smooth running of the wheels of government and development of an area is the planning stage. Manual planning is proven to have low accuracy, especially planning or estimating Local Government Revenue.

This study will forecast Local Government Revenue using data mining methods. The research is focused on the prediction of Local Government Revenue in Bandar Lampung with to find the most accurate prediction model in predicting the revenue of Bandar Lampung City's Local Government Revenue and evaluating the factors that most determine the prediction of Local Government Revenue realization. What is expected from this research is to assist local governments in preparing budgets, especially in determining the Local Government Revenue budget, so that the accuracy of the Local Government Revenue budget value and realization can be improved. By increasing the accuracy of budgeting, it was certainly improving the smooth implementation of government and regional development. 


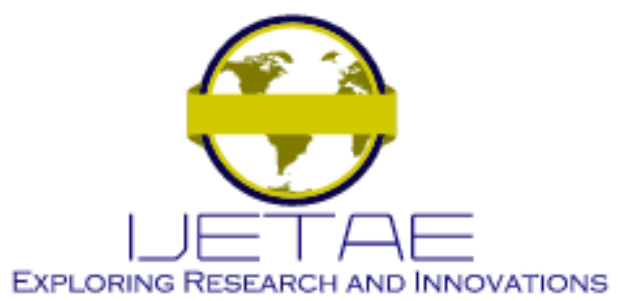

International Journal of Emerging Technology and Advanced Engineering

Website: www.ijetae.com (E-ISSN 2250-2459, Scopus Indexed, ISO 9001:2008 Certified Journal, Volume 12, Issue 01, January 2022)

In part II of this paper, we will discuss previous research related to data mining and forecasting. In part III, the method proposed in the study will be discussed. The research results and discussions that need to be carried out from the research will be discussed in part IV of this paper.

\section{RELATED WORKS}

In this study, modeling and forecasting of Local Government Revenue at the City Government of Bandar Lampung will be carried out using Multiple Linear Regression, Artificial Neural Networks (ANN), and Deep Learning methods.

Forecasting aims to predict the uncertainty of a trend in business that serves to make decisions that can affect the future of an organization, forecasting is done for the long term or short term. Forecasting as a science to predict the future has many approaches such as time series approaches, judgmental methods, and others (Hanke 2005). The types that are often used in forecasting the time series approach and judgmental forecasts (Ozlale2005).

Research (Reitano2018) shows that statistically internal and external factors in Pennsylvania have a significant influence on the accuracy of intergovernmental (state) revenue streams and local revenue streams. Millage rate, administrative costs, and revenue volatility are internal intergovernmental (state) factors that determine forecasting accuracy. In addition, political and economic shocks and exogenous policies that are not under the control of the government are external factors that affect forecast accuracy.

Two new revenue stream approaches, proposed by (Tofallis 2015): state revenue streams and local revenue streams. This analysis shows the consideration of factors that support optimism about sources of original and interregional income.

From the research that has been done (Budgeting2016), it is recommended to choose the damped trend forecasting method and the Linear Regression method because it works better on monthly and quarterly data.

According to (Billah 2006), simulation studies are used as an approach to choose the appropriate forecasting method. Simulation studies are also compared with a time series of M3 forecasting. The results showed that for the automatic method the information criteria became the best basis for the selection of the method.
(Reddick 2004) examined the relationship between four similarities in income forecasting techniques. The results show above $50 \%$ of respondents for deterministic forecasting and $20 \%$ of respondents for econometric forecasting to indicate cities that use simple causal forecasting. In addition, forecasting based on trends and using expert judgment is carried out by approximately $90 \%$ of local governments based on survey results. When cities use causal income estimation techniques, they rely on an inaccurate method of expert judgment.

According to (ostertagova2011), the selection of the smoothing constant has a big influence in determining the characteristics of the Linear Regression operation. For short-term forecasts with non-seasonal patterns and trends close to zero, the Linear Regression Model is good to use. If the forecast extends beyond the next period, the estimated value for that period should be used instead of actual demand after the next period.

(Reitano2018) stated, in order to face the "New Normal" in financial management after the Great Recession that occurred, state and local governments need to do forecasting, in planning and minimizing the effects of an uncertain situation forecasting has proven important.

In his research (Himawan2020) compared the accuracy of forecasting to data on new student admissions in a study program at a university using the Triple Exponential Smoothing, Double Exponential Smoothing, and Single Exponential Smoothing methods. From the forecasting that has been done, it is concluded that Triple Exponential Smoothing is the best with an MPE value of 0.0161 .

In forecasting Console Game sales in the Italian market, (Rossetti2019) compared two forecasting models, namely exponential smoothing with a damped trend and the SARIMA model. The result is that the Sarima model becomes the relevant and most reliable model in forecasting console game sales analysis.

(Salinas2020) proposed the DeepAr model which is considered effective in studying the associated Global Time Series model, can handle large-scale data variations through re-scaling and velocity base is used in sampling, resulting in calibrated probilistic estimates with high accuracy. DeepAR has the ability to study data that has complex patterns such as seasonal growth and indeterminate data. 


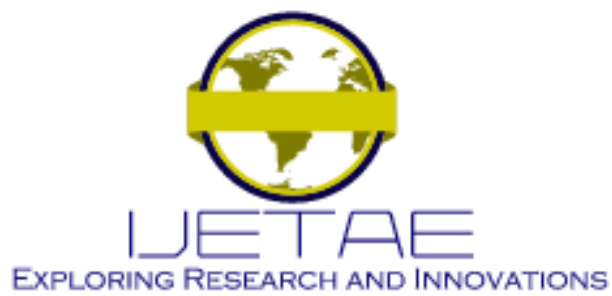

International Journal of Emerging Technology and Advanced Engineering Website: www.ijetae.com (E-ISSN 2250-2459, Scopus Indexed, ISO 9001:2008 Certified Journal, Volume 12, Issue 01, January 2022)

(Shahid2020) conducted research on the prediction of the daily closing stock price of the big tech giant NSE (namely HCL TECH and TCS), the data used were historical data and used the Exponential Smoothing method. As training data and test data used historical data on stock prices for three years. The Holt-Winter method with Exponential Smoothing gives the best results compared to combining the Exponential Smoothing method with other methods

In his research, (Nor2018) chooses a forecasting model based on the accuracy that has the lowest value. The research conducted shows that the most optimal method for estimating the general annual unemployment rate, the annual male unemployment rate, and the quarterly overall unemployment rate is the Holt Method. While the SES method gives the best results for forecasting the annual unemployment rate for female and the general unemployment rate in the monthly period.

(Khashei2010) argues that one of the flexible computing frameworks and has a universal approach that is suitable for use in various forecasting problems with time series data and a high degree of accuracy is Artificial Neural Networks (ANN).

(Tealab2018) studied the progress of forecasting methods for time series data using the Artificial Neural Network model. The results obtained indicate that there are still few proposals related to the New Artificial Neural Network model, although the application of the Artificial Neural Network model has been presented by many researchers. Not many researchers have considered theoretical factors and systematic procedures. So formulating a new model of neural networks is important.
A study conducted by (Al-Gabalawy2021) showed that the application of the Deep Learning method is feasible for forecasting energy time series and produces good forecasts in forecasting and the Deep Learning method continues to be widely applied in new fields, including energy time series forecasting.

CRISP-DM has been around for two decades. From the survey results and various polls conducted to users, CRISPDM is still a very common standard used in the development of data mining and knowledge mining. (Martinez-Plumed2019).

The CRISP-DM method is collaborated with a quality management tool with the aim of guiding novice data mining users and is called QMCRISP-DM. The project of a production error forecasting system in the electronics industry was used to validate the QMCRISP-DM method (Schafer2019).

(CELIK2017) uses the Artificial Neural Network method with RapidMiner software to predict the future prices of various precious metals such as silver, gold, platinum, and palladium. The price data used is the period of January 4, 2010, to December 14, 2015. For forecasting and validation, prices are used in the fourth quarter of 2015. The results show that there is a high degree of accuracy for predicting market trends.

From the research conducted in (Lee2021), Deep Learning Method Gives good expectations for forecasting data that are time series, temporary, trending, and seasonal.

According to (Sezer2019), recently the Deep Learning (DL) model has been used in machine learning applications especially for financial time series forecasting and shows results that significantly outperform traditional machine learning models. The summary of the related works that has been carried out is shown in tabular form, as shown in Table I. 


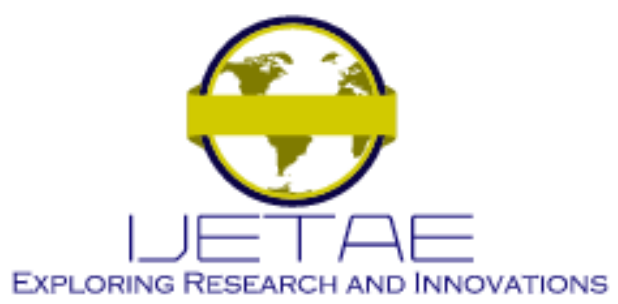

International Journal of Emerging Technology and Advanced Engineering

Website: www.ijetae.com (E-ISSN 2250-2459, Scopus Indexed, ISO 9001:2008 Certified Journal, Volume 12, Issue 01, January 2022)

TABLE I

RECAPITULATION OF RESEARCH RESULTS RELATED TO FORECASTING

\begin{tabular}{|c|c|c|c|}
\hline Num & Publication & Method & Evaluation Result \\
\hline 1 & $\begin{array}{l}\text { (Budgeting201 } \\
6 \text { ) }\end{array}$ & $\begin{array}{l}\text { Damped trend } \\
\text { and Linear } \\
\text { Regression }\end{array}$ & $\begin{array}{l}\text { Linear Regression } \\
\text { best performing with } \\
\text { monthly and quarterly } \\
\text { data. }\end{array}$ \\
\hline 2 & (Billah2006) & $\begin{array}{l}\text { Information } \\
\text { criteria approach } \\
\text { and } \\
\text { Encompassing } \\
\text { approach }\end{array}$ & $\begin{array}{l}\text { The information } \\
\text { criteria approach } \\
\text { provides the best } \\
\text { basis for automated } \\
\text { method selection. }\end{array}$ \\
\hline 3 & (Khan2020) & $\begin{array}{l}\text { ARIMA and } \\
\text { NAR }\end{array}$ & $\begin{array}{l}\text { NAR optimized using } \\
\text { Levenberg-Marquardt } \\
\text { (LM) has the highest } \\
\text { overall } R^{2} \text {. value of } \\
0.97 \text {. }\end{array}$ \\
\hline 4 & (Reddick2004) & $\begin{array}{l}\text { Simple Causal } \\
\text { Forecasting: } \\
\text { Deterministic } \\
\text { and } \\
\text { Econometric }\end{array}$ & $\begin{array}{lr}\text { Accuracy } & \text { with } \\
\text { Deterministic } & \text { by } \\
50 \%, & \text { and } \\
\text { Econometric by } 20 \%\end{array}$ \\
\hline 5 & $\begin{array}{l}\text { (Ostertagova20 } \\
11)\end{array}$ & $\begin{array}{l}\text { Linear } \\
\text { Regression } \\
\text { Model }\end{array}$ & $\begin{array}{l}\text { For short-term } \\
\text { forecasting and data } \\
\text { with seasonal patterns } \\
\text { Linear Regression } \\
\text { method gives good } \\
\text { results. }\end{array}$ \\
\hline 6 & $\begin{array}{l}\text { Vincent } \\
\text { Reitano }\end{array}$ & Forecasting & $\begin{array}{l}\text { Forecasting } \\
\text { proven to be very } \\
\text { important for } \\
\text { planning and } \\
\text { mitigating the effects } \\
\text { of environmental } \\
\text { uncertainty. }\end{array}$ \\
\hline 7 & $\begin{array}{l}\text { (Himawan } 2020 \\
\text { ) }\end{array}$ & $\begin{array}{l}\text { Single } \\
\text { exponential } \\
\text { smoothing, } \\
\text { Double } \\
\text { exponential } \\
\text { smoothing and } \\
\text { Triple } \\
\text { exponential }\end{array}$ & $\begin{array}{l}\text { The triple exponential } \\
\text { smoothing method } \\
\text { shows the best } \\
\text { prediction results } \\
\text { with an MPE value of } \\
0.0161 \text {. }\end{array}$ \\
\hline
\end{tabular}

\begin{tabular}{|c|c|c|c|}
\hline & & smoothing. & \\
\hline 8 & $\begin{array}{l}\text { (Al- } \\
\text { Gabalawy2021 }\end{array}$ & Deep Learning & $\begin{array}{l}\text { The application of the } \\
\text { Deep Learning } \\
\text { method is feasible for } \\
\text { the energy field, } \\
\text { especially time series } \\
\text { data, and produces } \\
\text { good forecasts and } \\
\text { continues to be } \\
\text { developed. }\end{array}$ \\
\hline 9 & (Salinas2020) & $\overline{\text { DeepAR }}$ & $\begin{array}{l}\text { Has high accuracy, } \\
\text { has the ability to } \\
\text { study data that has } \\
\text { complex patterns } \\
\text { such as seasonal } \\
\text { growth and } \\
\text { indeterminate data. }\end{array}$ \\
\hline 10 & $\begin{array}{l}\text { (Martinez- } \\
\text { Plumed2019) }\end{array}$ & CRISP-DM & $\begin{array}{l}\text { CRISP-DM is a very } \\
\text { common standard } \\
\text { used in the } \\
\text { development of data } \\
\text { mining and } \\
\text { knowledge mining. }\end{array}$ \\
\hline 11 & (Schafer2019) & $\begin{array}{l}\text { QM-CRISP-DM } \\
\text { and CRISP-DM }\end{array}$ & $\begin{array}{l}\text { QMCRISP-DM is a } \\
\text { continuation } \\
\text { CRISP-DM }\end{array}$ \\
\hline 12 & (CELIK2017) & $\begin{array}{l}\text { Artificial Neural } \\
\text { Network }\end{array}$ & $\begin{array}{l}\text { ANN provides a high } \\
\text { level of accuracy for } \\
\text { predicting market } \\
\text { trends }\end{array}$ \\
\hline 13 & (Lee2021) & Deep Learning & $\begin{array}{lr}\text { Gives } & \text { good } \\
\text { expectations } & \text { for } \\
\text { forecasting data that } \\
\text { are time series, } \\
\text { temporary, trending, } \\
\text { and seasonal. }\end{array}$ \\
\hline 14 & (Sezer2019) & Deep Learning & $\begin{array}{l}\text { Shows results that } \\
\text { significantly } \\
\text { outperform traditional } \\
\text { machine learning } \\
\text { models in time series } \\
\text { forecasting related to } \\
\text { financial data. }\end{array}$ \\
\hline
\end{tabular}




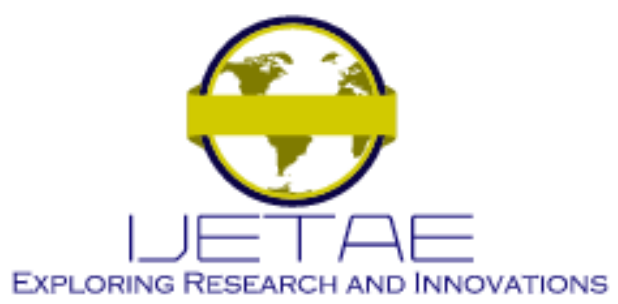

International Journal of Emerging Technology and Advanced Engineering

Website: www.ijetae.com (E-ISSN 2250-2459, Scopus Indexed, ISO 9001:2008 Certified Journal, Volume 12, Issue 01, January 2022)

Very rarely forecasts give perfect results. There are many uncertainties in the future that affect forecasting. Therefore, making perfect predictions is something that is almost impossible. From the literature review above, it can be concluded that the Multiple Linear Regression, Neural Network and Deep Learning methods have a better accuracy rate than other methods, especially for forecasting using time series data.

Local Government Revenue forecasting at the Bandar Lampung City Government which will be carried out in this study will use the Multiple Linear Regression, Artificial Neural Network and Deep Learning methods because the data to be processed is time series data.

\section{PROPOSED METHOD}

\section{A. Research Stages}

The stages of the research carried out in this study are depicted in Figure 1. With a focus on the prediction of local revenue in the City Government of Bandar Lampung, this study will be able to contribute to the evaluation process of planning and budgeting in local governments, especially budgeting related to local revenue.

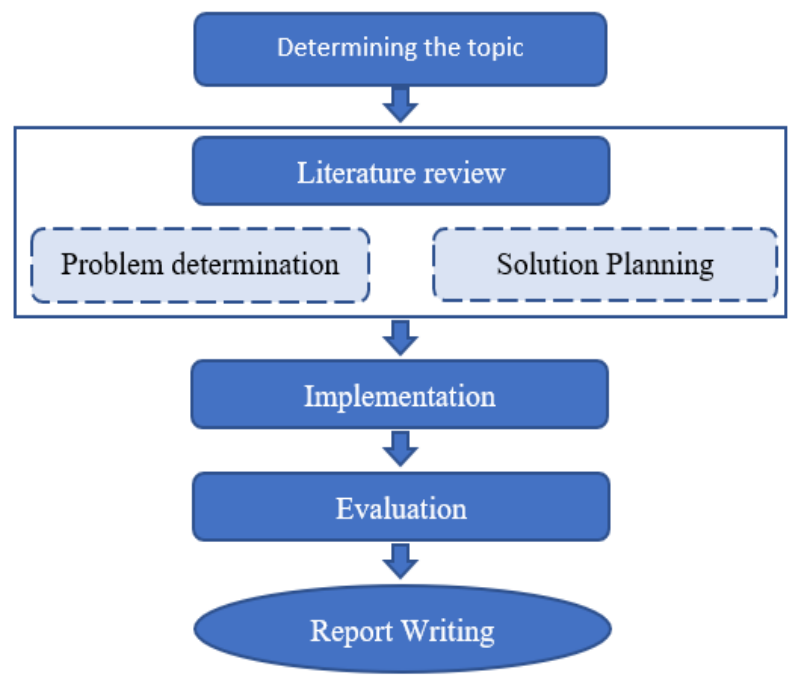

Figure 1: Research Stage

In detail, this research was conducted with research stages divided into seven stages, namely:

1. Determining the topic, the topic of this research is a case study by predicting the Local Government Revenue of Bandar Lampung City based on Local Government Revenue data in the period 2010 to 2020.
2. Literature review, literature review needs to be carried out related to previous studies, especially research related to datamining and forecasting.

3. Problem Formulation, The problem formulation in this thesis is to find the factors that most determine the prediction of Local Government Revenue acceptance, what prediction model gives the best accuracy, and optimize the prediction model to get the best results.

4. Solution Planning, the solution design carried out in this thesis will use the CRISP-DM frame work.

5. Implementation, this research will be implemented using Rapid Miner software.

6. Evaluation, the results of this study will be evaluated using RMSE and $\mathrm{R}^{2}$ testing data

7. Report Writing. reports the best method based on the results of performance measurement and influencing factors in the prediction.

B. Data Mining Stages for Prediction of Local Government Revenue

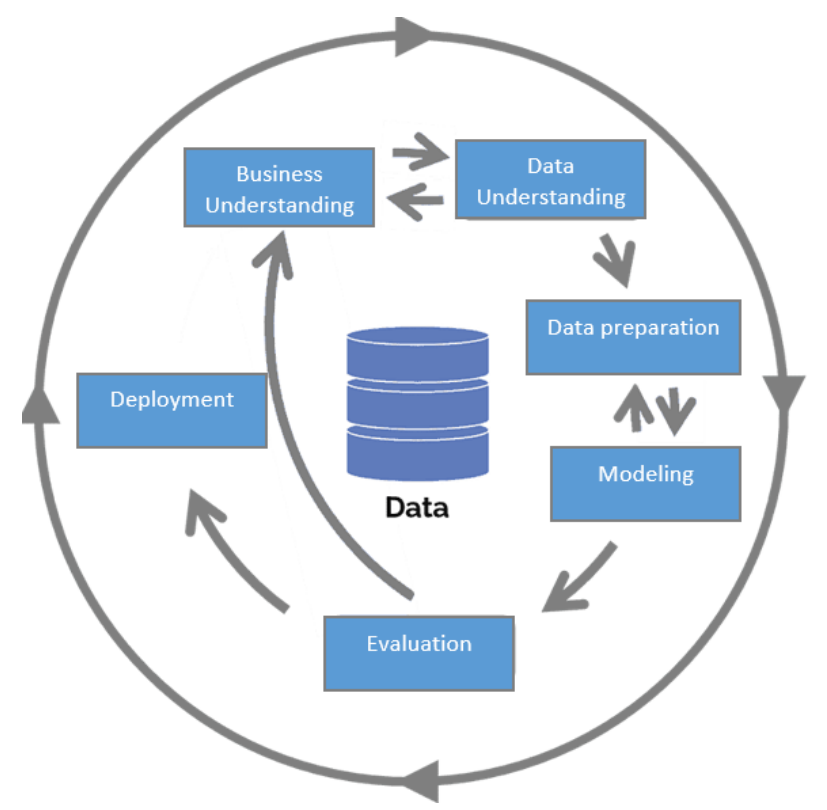

Figure 2: CRISP-DM life cycle (Ncr2000)

This study uses the CRISP-DM framework (Ncr2000), with a research flow as shown in Figure 2. The data in this study were obtained from monthly reports of all types of local revenue in the city of Bandar Lampung, namely local taxes, regional levies, separate wealth management, and other legal income from 2010 to 2020. 


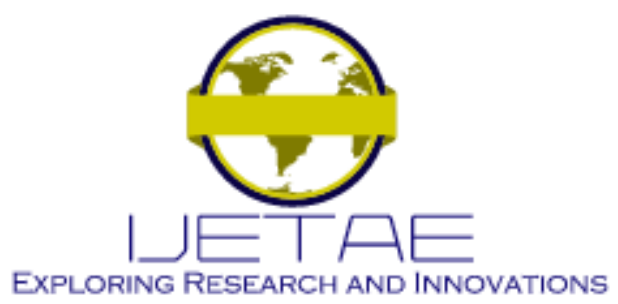

International Journal of Emerging Technology and Advanced Engineering Website: www.ijetae.com (E-ISSN 2250-2459, Scopus Indexed, ISO 9001:2008 Certified Journal, Volume 12, Issue 01, January 2022)

The research carried out included phases Business understanding, data understanding, data preparation, modeling, and evaluation.

\section{Business understanding}

To find out the business needs of the Bandar Lampung City Government, especially those related to budgeting, a discussion was held with the Bandar Lampung City Government Budget Team, both as a team and individually. From the results of the discussion, information is obtained that so far the budget team has been determined by the budget team manually and based on the experience of the previous year so that the achievement value is often far from the target. We need a new way to predict local revenue for the coming year. In addition, information is obtained about the variables used to predict, including the realization data of the previous year and the economic indicators of the previous year.

\section{Data understanding}

In this study, various data from various sources will be used, such as data from the Bandar Lampung City Government in the form of Financial Report data from 2010 to 2020, Tax and Levy Revenue data, and Economic Indicator data. In addition, data was also obtained from the Central Statistics Agency for the City of Bandar Lampung in the form of a document "Bandar Lampung Dalam Angka" which contains economic indicators for 2010 to 2020. The statistics of the data to be used are shown in Table II. The data to be processed consists of 13 attributes, and it appears that there is no missing value.
TABLE II

STATISTICS OF THE DATA TO BE USED

\begin{tabular}{|c|c|c|c|c|c|}
\hline \multirow{2}{*}{ NAME } & \multirow{2}{*}{$\begin{array}{c}\text { TYP } \\
\text { E }\end{array}$} & \multirow{2}{*}{$\begin{array}{c}\text { MISSIN } \\
\text { G }\end{array}$} & \multicolumn{3}{|c|}{ STATISTIC } \\
\hline & & & Min & Max & Average \\
\hline PAD Y+1 & Real & 0 & $\begin{array}{r}8372225033 . \\
000 \\
\end{array}$ & $\begin{array}{r}627296544826 . \\
640 \\
\end{array}$ & $\begin{array}{r}201159470223 . \\
467 \\
\end{array}$ \\
\hline PAD Y & Real & 0 & 0 & 1 & 0.290 \\
\hline $\begin{array}{c}\text { Economic } \\
\text { Growth } \\
(\%)\end{array}$ & Real & 0 & 0 & 1 & 0.439 \\
\hline $\begin{array}{c}\text { Inflation } \\
(\%)\end{array}$ & Real & 0 & 0 & 1 & 0.479 \\
\hline GRDP (Rp) & Real & 0 & 0 & 1 & 0.519 \\
\hline $\begin{array}{c}\text { minimum } \\
\text { wages }\end{array}$ & Real & 0 & 0 & 1 & 0.490 \\
\hline $\begin{array}{c}\text { Number of } \\
\text { Hotels }\end{array}$ & Real & 0 & 0 & 1 & 0.479 \\
\hline $\begin{array}{c}\text { Number of } \\
\text { Restaurant } \\
\text { s }\end{array}$ & Real & 0 & 0 & 1 & 0.440 \\
\hline $\begin{array}{l}\text { Number of } \\
\text { Entertainm } \\
\text { ent Venues }\end{array}$ & Real & 0 & 0 & 1 & 0.647 \\
\hline $\begin{array}{c}\text { Number of } \\
\text { Billboards } \\
\text { (SKPD) }\end{array}$ & Real & 0 & 0 & 1 & 0.454 \\
\hline $\begin{array}{c}\text { Number of } \\
\text { Residents } \\
\text { (People) }\end{array}$ & Real & 0 & 0 & 1 & 0.501 \\
\hline Ship Visits & Real & 0 & 0 & 1 & 0.505 \\
\hline $\begin{array}{l}\text { Export } \\
\text { Volume } \\
\text { (Tons) }\end{array}$ & Real & 0 & 0 & 1 & 0.626 \\
\hline $\begin{array}{l}\text { Import } \\
\text { Volume } \\
\text { (Tons) }\end{array}$ & Real & 0 & 0 & 1 & 0.572 \\
\hline
\end{tabular}

\section{Data preparation}

The data that will be processed first will be cleaned to remove noise and inconsistent or irrelevant data, the initial data that has been successfully collected consists of 36 variables but there are some inconsistent data such as data that does not appear every year or data that is new in 3rd year and also duplicated data because the same data is contained in different documents. 


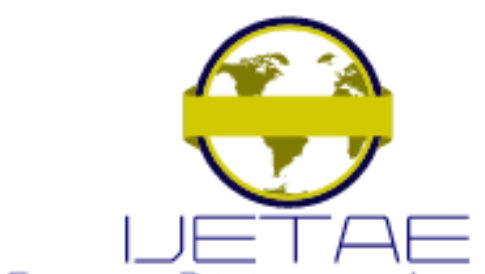

EXPLORING RESEARCH AND INNOVATIONS

International Journal of Emerging Technology and Advanced Engineering

Website: www.ijetae.com (E-ISSN 2250-2459, Scopus Indexed, ISO 9001:2008 Certified Journal, Volume 12, Issue 01, January 2022)

There are also inaccurate data due to improvements after the audit. The 36 initial variables that have been successfully collected consist of: Realization of Local Government Revenue, Local Tax Revenue, Hotel Tax, Restaurant Tax, Entertainment Tax, Advertisement Tax, Street Lighting Tax, Parking Tax, Groundwater Tax, NonMetal Rock and Rock Tax, Property Tax, Land and Building Rights Acquisition Fee, Regional Retribution Income, General Service Fee, Business Service Fee, Certain Licensing Fees, Revenue from Separated Regional Wealth Management, Profit from Regional Owned Company, Other Legitimate Local Revenue, Regional Asset Sales Results, Current account service, Claims for Regional, Compensation, Miscellaneous Receipts, Public Service Agency Revenue, Economic Growth, Inflation, Gross Regional Domestic Product (GRDP), Minimum Wage, Number of Hotels, Number of Restaurants, Number of Entertainment Venues, Number of Billboards, Number of Residents, Ship Visits, Export Volume, and Import Volume.

From the results of data cleaning, 13 attributes are produced that will be used in forecasting, namely, Realization of Local Government Revenue, Economic Growth, Inflation, Gross Regional Domestic Product (GRDP), Minimum Wages, Number of Hotels, Number of Restaurants, Number of Entertainment Venues, Number of Billboards, Number of Residents, Ship Visits, Export Volume, and Import Volume. The cleaned data will then be normalized using Rapid Miner as shown in Figure 3. The results of the normalization for the training data are shown in Figure 4, while the normalization results for the testing data are shown in Figure 5.
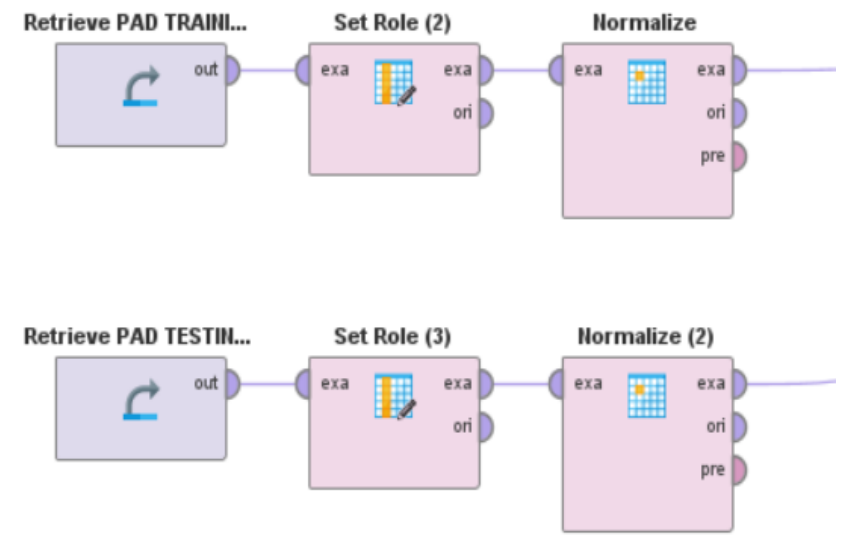

Figure 3: Data Normalization Process

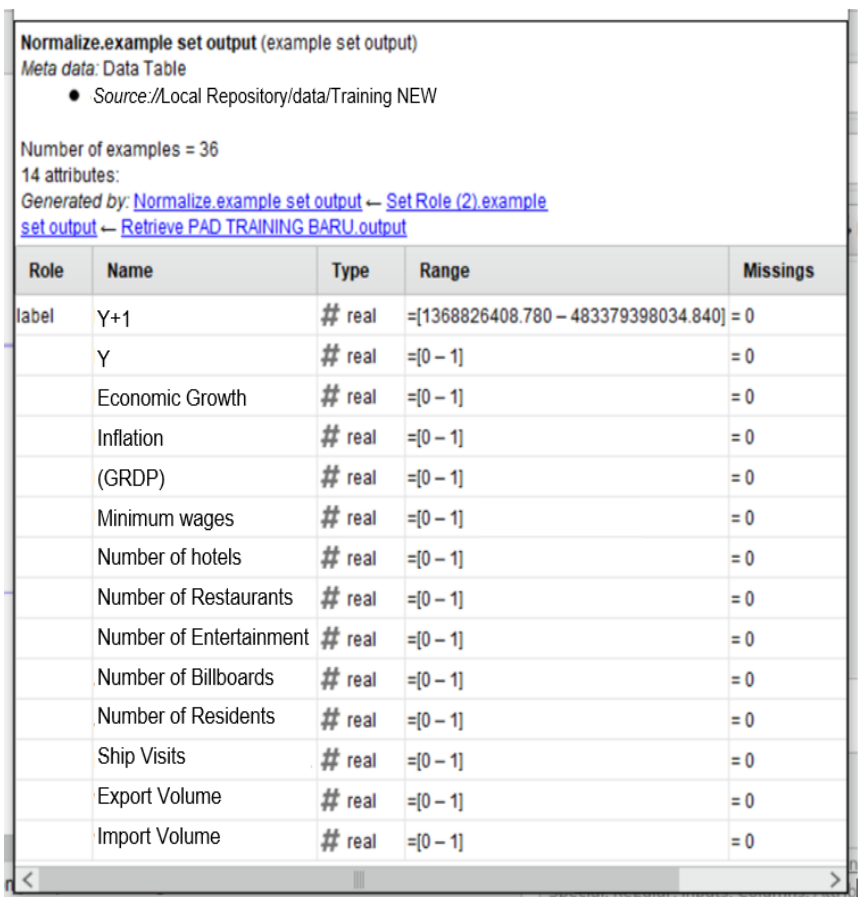

Figure 4: Normalization of Training Data

\begin{tabular}{|c|c|c|c|c|}
\hline \multicolumn{5}{|c|}{$\begin{array}{l}\text { Normalize (2).example set output (example set output) } \\
\text { Meta data: Data Table } \\
\quad \text { - Source://Local Repository/data/Testing NEW } \\
\text { Number of examples = } 18 \\
14 \text { attributes: } \\
\text { Generated by: Normalize (2). example set output } — \text { Set Role (3). } \\
\text { example set output } — \text { Retrieve PAD TESTING BARU.output }\end{array}$} \\
\hline Role & Name & Type & Range & Missings \\
\hline \multirow[t]{14}{*}{ label } & $\mathrm{Y}+1$ & \# real & $=[8372225033.000-627296544826.640]$ & $=0$ \\
\hline & Y & \# real & $=[0-1]$ & $=0$ \\
\hline & Economic Growth & \# real & $=[0-1]$ & $=0$ \\
\hline & Inflation & $\#$ real & $=[0-1]$ & $=0$ \\
\hline & (GRDP) & $\#$ real & $=[0-1]$ & $=0$ \\
\hline & Minimum wages & \# real & $=[0-1]$ & $=0$ \\
\hline & Number of hotels & $\#$ real & $=[0-1]$ & $=0$ \\
\hline & Number of Restaurants & $\#$ real & $=[0-1]$ & $=0$ \\
\hline & Number of Entertainment & \# real & $=[0-1]$ & $=0$ \\
\hline & Number of Billboards & \# real & $=[0-1]$ & $=0$ \\
\hline & Number of Residents & $\#$ real & $=[0-1]$ & $=0$ \\
\hline & Ship Visits & \# real & $=[0-1]$ & $=0$ \\
\hline & Export Volume & \# real & $=[0-1]$ & $=0$ \\
\hline & Import Volume & \# real & $=[0-1]$ & $=0$ \\
\hline
\end{tabular}

Figure 5: Normalization of Testing Data 


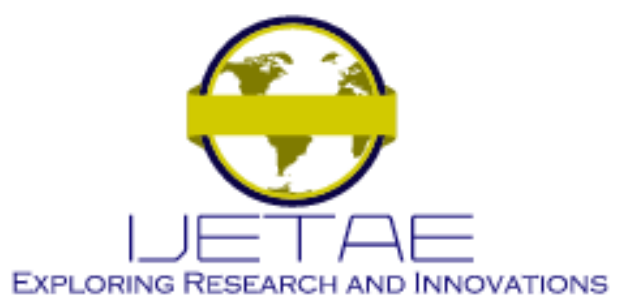

International Journal of Emerging Technology and Advanced Engineering

Website: www.ijetae.com (E-ISSN 2250-2459, Scopus Indexed, ISO 9001:2008 Certified Journal, Volume 12, Issue 01, January 2022)

\section{Modelling}

This study performs modeling using the Multiple Linear Regression method as shown in Figure 6, the Artificial Neural Network (ANN) method as shown in Figure 7, and Deep Learning as shown in Figure 8. These three methods were chosen because the research conducted forecasting of Local Government Revenue which is a time series data. While the tool that will be used in this research is Rapid Miner. Rapid Miner was chosen for its proven reliability and ease of use.

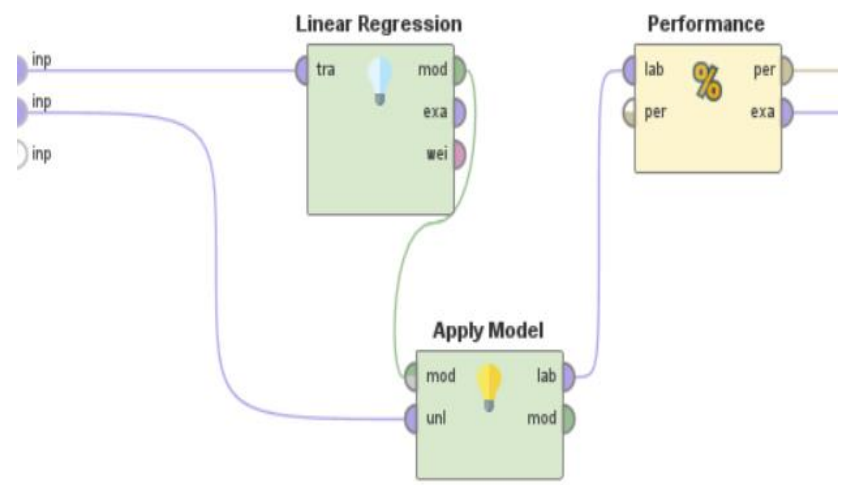

Figure 6: Linear Regression Modeling

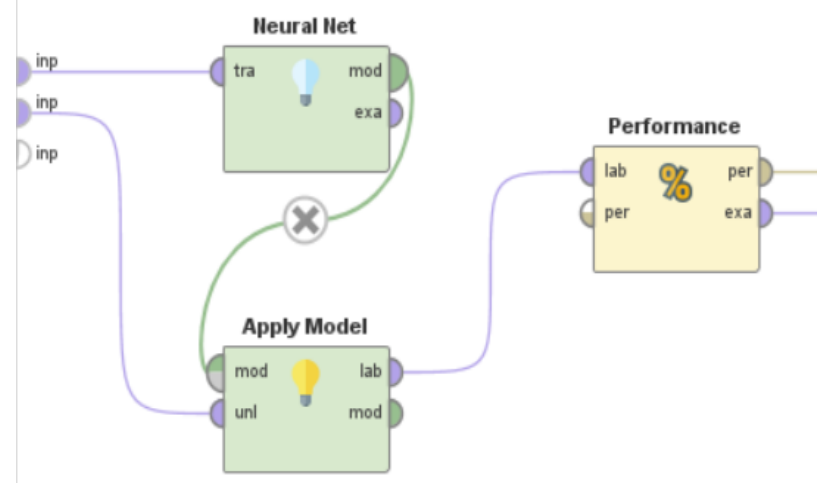

Figure 7: ANN Modeling

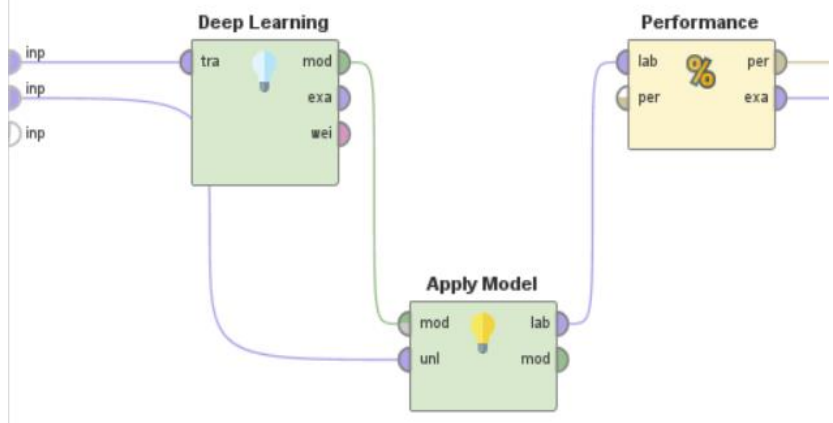

Figure 8: Deep Learning Modeling

\section{Tuning Parameters}

In this study, parameter tuning was carried out. The tuning parameters are executed for each method to be used. Parameters tuned in this study are shown in Table III.

TABLE III

Tuning Parameters

\begin{tabular}{|l|l|}
\hline \multicolumn{1}{|c|}{ Model } & \multicolumn{1}{c|}{ Parameter } \\
\hline Linear Regression & Alpha \\
\hline ANN & Learning rate \\
\hline ANN & Momentum \\
\hline ANN & Error epsilon \\
\hline Deep Learning & Learning rate \\
\hline Deep Learning & Learning rate annealing \\
\hline
\end{tabular}

\section{Evaluation}

The data will be broken down into three parts, namely training data which functions to train the model $(60 \%)$, validation data $(20 \%)$ for tuning parameters, and testing data $(20 \%)$ to measure performance. Training data is obtained from Local Government Revenue data for the period 2010 to 2016, validation data uses Local Government Revenue data for 2017 and 2018, testing data used is Local Government Revenue data for 2019 and 2020. 


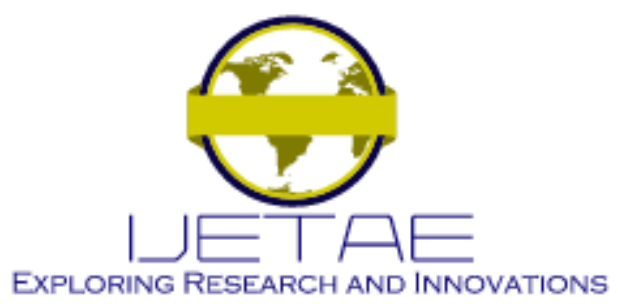

International Journal of Emerging Technology and Advanced Engineering

Website: www.ijetae.com (E-ISSN 2250-2459, Scopus Indexed, ISO 9001:2008 Certified Journal, Volume 12, Issue 01, January 2022)

Performance measurement in this study will use the Root Mean Squared Error (RMSE) and $\mathrm{R}^{2}$ methods. RMSE measures the level of accuracy of a model in making estimates. RMSE calculation is done by squaring the error then divided by the amount of data. (= average), then rooted. RMSE has no units and can be formulated as follows:

$$
\operatorname{RMSE}=\left(\frac{\Sigma\left(y_{i}-\hat{y}_{i}\right)}{\mathrm{n}}\right)^{1 / 2}
$$

where:

$$
\begin{aligned}
& \mathrm{y}=\text { the value of the observation result } \\
& \hat{\mathrm{y}}=\text { predicted value } \\
& \mathrm{I}=\text { sequence of data in the database } \\
& \mathrm{n}=\text { is the amount of data }
\end{aligned}
$$

$\mathrm{R}^{2}$ serves to measure how much the independent variable $(\mathrm{X})$ is related to the dependent variable $(\mathrm{Y}) . \mathrm{R}^{2}$ has a value of zero to one. If the dependent variable has a low attachment to the independent variable, then the value of $R^{2}$ is close to zero. The value of $\mathrm{R}^{2}$ which is getting closer to the number one indicates a high correlation between the independent variable and the dependent variable. The formula for measuring $\mathrm{R}^{2}$ can be written as follows:

$$
r^{2}=\frac{\text { regression sum of squares }}{\text { total sum of squares }}=\frac{S S R}{S S T}
$$

\section{RESUlts AND Discussion}

In this study the data used are economic indicator data such as data on Economic Growth, Inflation Rate, Gross Regional Domestic Product (GRDP), City Minimum Wage, Number of Hotels, Number of Restaurants, Number of Entertainment venues, Number of Billboards, Number of Residents, number of ship visits, export and import volumes. during the period 2010 to 2020 . The software used in this research is Rapid Miner Studio 9.9 and uses the CRISP-DM Framework. The performance of the model under study was measured using the Root Mean Square Error (RMSE) and Coefficient of Determination $\left(\mathrm{R}^{2}\right)$ methods.

\section{Multiple Linear Regression}

By using a Multiple Linear Regression model, the test results show that the RMSE performance value is $97,235,653,345.288$ and the coefficient determination value, $\mathrm{R}^{2}$ is 0.942 . Comparison of forecast value and reality value can be seen in Table IV.

TABLE IV

MULTIPLE LiNEAR REgRESSION FORECASTING RESUlT

\begin{tabular}{|r|r|}
\hline Y+1 & Prediction Y+1 \\
\hline $612,809,680,623.87$ & $418,829,928,130.10$ \\
\hline $550,275,048,130.32$ & $459,600,618,666.91$ \\
\hline $627,296,544,826.64$ & $405,814,707,510.53$ \\
\hline $373,764,303,246.73$ & $296,476,977,857.49$ \\
\hline $398,448,008,992.24$ & $275,317,809,233.49$ \\
\hline $480,420,824,001.04$ & $288,769,510,371.32$ \\
\hline $28,256,993,503.00$ & $84,465,549,327.02$ \\
\hline $29,579,486,070.00$ & $8,962,281,182.84$ \\
\hline $29,626,488,615.00$ & $4,404,556,480.50$ \\
\hline $13,461,922,795.62$ & $54,579,739,579.16$ \\
\hline $14,894,667,167.54$ & $(2,443,407,668.53)$ \\
\hline $17,468,775,203.28$ & $(6,916,137,996.25)$ \\
\hline $197,238,578,727.52$ & $121,732,153,819.71$ \\
\hline $107,352,885,900.54$ & $139,232,113,669.73$ \\
\hline $99,780,457,007.32$ & $64,360,957,968.86$ \\
\hline $12,211,420,793.22$ & $59,798,934,206.74$ \\
\hline $19,612,153,385.53$ & $(3,407,433,933.06)$ \\
\hline $8,372,225,033.00$ & $(3,279,374,034.31)$ \\
\hline
\end{tabular}

\section{Artificial Neural Network (ANN)}

The test performance with the Artificial Neural Network method shows an RMSE value of 135,135,006,607.010 and an $\mathrm{R}^{2}$ value of 0.911 , with a comparison of forecast and reality values as shown in Table $\mathrm{V}$. 


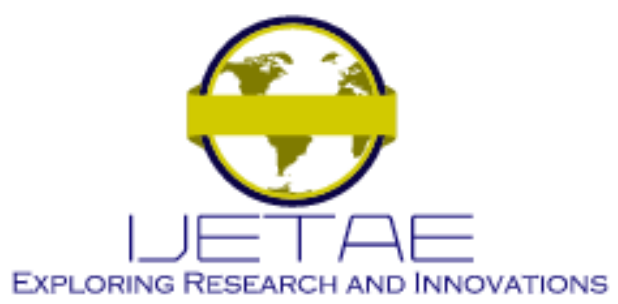

International Journal of Emerging Technology and Advanced Engineering

Website: www.ijetae.com (E-ISSN 2250-2459, Scopus Indexed, ISO 9001:2008 Certified Journal, Volume 12, Issue 01, January 2022)

TABLE V

ANN FORECASTING RESULT

\begin{tabular}{|r|r|}
\hline Y+1 & \multicolumn{1}{|c|}{ Prediction Y+1 } \\
\hline $612,809,680,623.87$ & $367,665,676,874.22$ \\
\hline $550,275,048,130.32$ & $405,536,240,432.99$ \\
\hline $627,296,544,826.64$ & $346,480,355,202.15$ \\
\hline $373,764,303,246.73$ & $254,568,882,358.97$ \\
\hline $398,448,008,992.24$ & $233,521,876,875.29$ \\
\hline $480,420,824,001.04$ & $235,452,705,112.50$ \\
\hline $28,256,993,503.00$ & $133,051,521,654.72$ \\
\hline $29,579,486,070.00$ & $101,914,804,994.48$ \\
\hline $29,626,488,615.00$ & $76,460,686,326.19$ \\
\hline $13,461,922,795.62$ & $121,492,758,492.51$ \\
\hline $14,894,667,167.54$ & $98,331,053,305.61$ \\
\hline $17,468,775,203.28$ & $73,017,013,117.45$ \\
\hline $197,238,578,727.52$ & $149,060,471,827.63$ \\
\hline $107,352,885,900.54$ & $153,111,151,370.73$ \\
\hline $99,780,457,007.32$ & $97,705,987,255.52$ \\
\hline $12,211,420,793.22$ & $123,434,655,496.14$ \\
\hline $19,612,153,385.53$ & $98,033,817,171.89$ \\
\hline $8,372,225,033.00$ & $74,105,141,189.17$ \\
\hline
\end{tabular}

\section{Deep Learning}

In predicting this Local Government Revenue, the Deep Learning model has a performance with an RMSE value of $104,342,330,445.749$ and $\mathrm{R}^{2}$ of 0.846 . Forecasting results can be seen in Table VI.
TABLE VI

DEEP LEARNING FORECASTING RESULT

\begin{tabular}{|r|r|}
\hline $\mathbf{Y + 1}$ & \multicolumn{1}{|c|}{ Prediction Y+1 } \\
\hline $612,809,680,623.87$ & $534,213,175,864.15$ \\
\hline $550,275,048,130.32$ & $441,393,956,447.97$ \\
\hline $627,296,544,826.64$ & $412,286,034,838.85$ \\
\hline $373,764,303,246.73$ & $421,316,006,696.07$ \\
\hline $398,448,008,992.24$ & $308,457,566,582.59$ \\
\hline $480,420,824,001.04$ & $316,677,860,029.36$ \\
\hline $28,256,993,503.00$ & $194,083,242,680.22$ \\
\hline $29,579,486,070.00$ & $17,448,285,053.21$ \\
\hline $29,626,488,615.00$ & $91,448,338,732.96$ \\
\hline $13,461,922,795.62$ & $160,939,655,746.15$ \\
\hline $14,894,667,167.54$ & $4,721,820,484.93$ \\
\hline $17,468,775,203.28$ & $81,591,339,259.14$ \\
\hline $197,238,578,727.52$ & $235,412,186,287.96$ \\
\hline $107,352,885,900.54$ & $169,321,683,736.42$ \\
\hline $99,780,457,007.32$ & $142,645,215,793.92$ \\
\hline $12,211,420,793.22$ & $166,727,781,693.70$ \\
\hline $19,612,153,385.53$ & $3,646,160,236.94$ \\
\hline $8,372,225,033.00$ & $84,800,516,272.64$ \\
\hline
\end{tabular}

The comparison of the performance test results using RMSE and $\mathrm{R}^{2}$ for the three prediction methods above is shown in Table VII. The comparison of the prediction results from the Multiple Linear Regression, Deep Learning, and Artificial Neural Network methods is shown in Figure 9. 


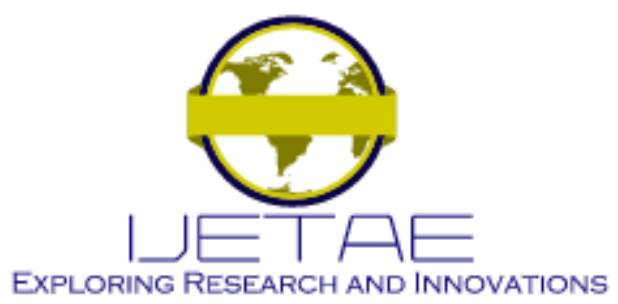

International Journal of Emerging Technology and Advanced Engineering

Website: www.ijetae.com (E-ISSN 2250-2459, Scopus Indexed, ISO 9001:2008 Certified Journal, Volume 12, Issue 01, January 2022)

TABLE VII

Performance Comparation

\begin{tabular}{|l|r|l|}
\hline \multicolumn{1}{|c|}{ Method } & \multicolumn{1}{c|}{ RMSE } & \multicolumn{1}{c|}{$\mathbf{R}^{\mathbf{2}}$} \\
\hline Linear Regression & $97,318,950,671.576$ & 0.949 \\
\hline ANN & $135,135,006,607.010$ & 0.911 \\
\hline Deep Learning & $104,342,330,445.749$ & 0.846 \\
\hline
\end{tabular}

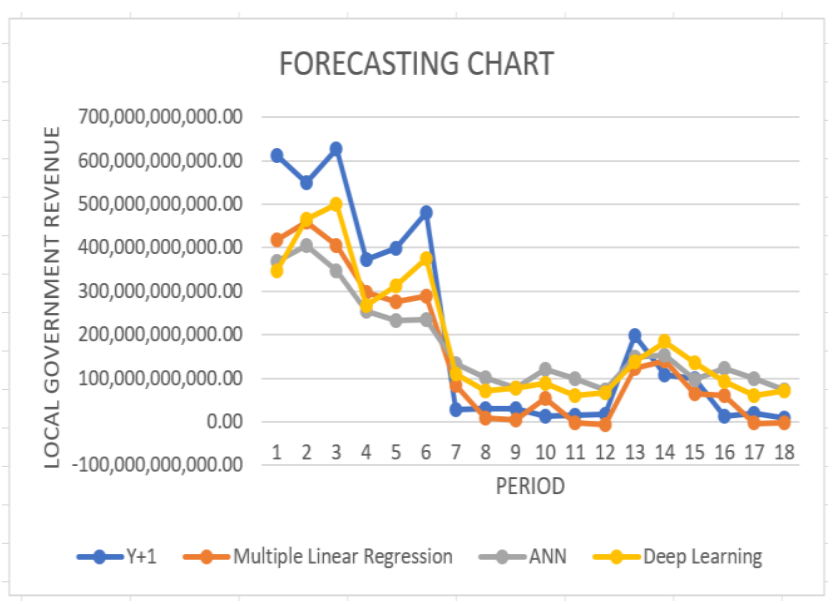

Figure 9: Forecasting Comparation

From the test results with three models, namely the Multiple Linear Regression model, Artificial Neural Network and the Deep Learning Model, it can be seen that the ANN method has a higher error value than the Deep Learning method, but the $\mathrm{R}^{2}$ value obtained by the ANN method is better than the Deep Learning method. Multiple Linear Regression Model has a better value than ANN or Deep Learning for measuring the $\mathrm{R}^{2}$ value. In measuring the performance of the error rate using the RMSE method, the Multiple Linear Regression method also shows a lower error rate when compared to ANN or Deep Learning.

In terms of forecasting results, the Multiple Linear Regression method shows better accuracy than the ANN and Deep Learning methods. These results indicate that the smaller the RMSE value will produce more accurate predictions and the larger the $\mathrm{R} 2$ value, the better the accuracy will be.

\section{CONCLUSION}

From the research conducted in the context of forecasting Local Government Revenue using the Multiple Linear Regression model, the Neural Network Model and the Deep Learning Model, it can be concluded that the performance of the Multiple Linear Regression method is better than the ANN and Deep Learning methods. The advantages of the Multiple Linear Regression method can be seen when measuring the performance and the predicted value generated.

The high RMSE value in this study may be due to the large value of the Local Government Revenue variable. However, further research is still needed by including other variables that have not been included in this study. A larger number of samples is likely to produce a better predictive value.

\section{Conflict of Interest}

The authors declare no conflict of interest.

\section{REFERENCES}

[1] Hanke, John E. Wichern, Dean W. Business Forecasting / John E Wichern Hanke .2005

[2] Özlale, Ü., \& Ozcan, K. (2005). Does Time Inconsistency Problem Apply For Turkish Monetary Policy? Working Papers, June.

[3] Reitano, V. (2018). An Open Systems Model of Local Government Forecasting. American Review of Public Administration, 48(5), 476-489. https://doi.org/10.1177/0275074017692876

[4] Tofallis, C. (2015). Erratum: A better measure of relative prediction accuracy for model selection and model estimation (Journal of the Operational Research Society. 66:3 (524) DOI: 10.1057/jors.2014.103)). Journal of the Operational Research Society, 66(3), 524. https://doi.org/10.1057/jors.2014.124

[5] Budgeting, J. O. F. P. (2016). LOCAL GOVERNMENT REVENUE FORECASTING METHODS: COMPETITION AND COMPARISON Daniel W. Williams and Shayne C. Kavanagh*. 28(4), 488-526.

[6] Billah, B., King, M. L., Snyder, R. D., \& Koehler, A. B. (2006). Exponential smoothing model selection for forecasting. International

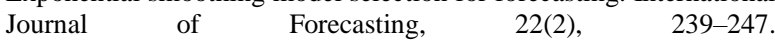
https://doi.org/10.1016/j.ijforecast.2005.08.002

[7] Reddick, C. G. (2004). Assessing Local Government revenue forecasting techniques. International Journal of Public Administration, 27(8-9), 597-613. https://doi.org/10.1081/PAD120030257 


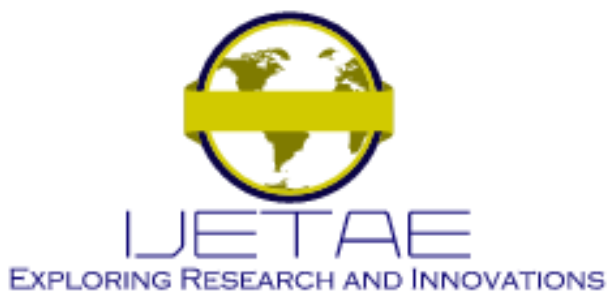

International Journal of Emerging Technology and Advanced Engineering

Website: www.ijetae.com (E-ISSN 2250-2459, Scopus Indexed, ISO 9001:2008 Certified Journal, Volume 12, Issue 01, January 2022)

[8] Ostertagová, E., Ostertag, O., Ostertagova, E., \& Ostertag, O. (2011). The Simple Exponential Smoothing Model. Modelling of Mechanical and Mechatronic Systems, May, 380-384. http://www.researchgate.net/publication/256088917_THE_SIMPLE _EXPONENTIAL_SMOOTHING_MODEL

[9] Himawan, H., \& Silitonga, P. D. P. (2020). Comparison of forecasting accuracy rate of exponential smoothing method on admission of new students. Journal of Critical Reviews, 7(2), 268274. https://doi.org/10.31838/jcr.07.02.50

[10] Rossetti, R. (2019). Forecasting the sales of console games for the Italian market. Econometrics, 23(3), 76-88. https://doi.org/10.15611/eada.2019.3.07

[11] Salinas, D., Flunkert, V., Gasthaus, J., \& Januschowski, T. (2020). DeepAR: Probabilistic forecasting with autoregressive recurrent networks. International Journal of Forecasting, 36(3), 1181-1191. https://doi.org/10.1016/j.ijforecast.2019.07.001

[12] Shahid, S., \& Rahaman, S. K. A. (2020). Exponential Smoothing Methods for Detection of the Movement of Stock Prices. International Journal of Recent Technology and Engineering, 8(5), 1420-1422. https://doi.org/10.35940/ijrte.e6409.018520

[13] Nor, M. E., Saharan, S., Lin, L. S., Salleh, R. M., \& Asrah, N. M. (2018). Forecasting of Unemployment Rate in Malaysia Using Exponential Smoothing Methods. International Journal of $\begin{array}{llll}\text { Engineering } \& \quad \text { Technology, } & \text { 7(4.30), } & 451 .\end{array}$ https://doi.org/10.14419/ijet.v7i4.30.22365

[14] M. Khashei, M. Bijari, "An artificial neural network (p, d, q) model for timeseries forecasting," Expert Systems with Applications, 37(1), 479-489, 2010, doi:10.1016/j.eswa.2009.05.044.
[15] A. Tealab, "Time series forecasting using artificial neural networks methodologies: A systematic review," Future Computing and Informatics Journal, 3(2), 334-340, 2018, doi:10.1016/j.fcij.2018.10.003.

[16] Al-Gabalawy, M., Hosny, N.S., \& Adly, A.R. (2021). Probabilistic forecasting for energy time series considering uncertainties based on deep learning algorithms. Electric Power Systems Research, 196, 107216.

[17] Martinez-Plumed, F., Contreras-Ochando, L., Ferri, C., Hernandez Orallo, J., Kull, M., Lachiche, N., Ramirez Quintana, M. J., \& Flach, P. A. (2019). CRISP-DM Twenty Years Later: From Data Mining Processes to Data Science Trajectories. IEEE Transactions on Knowledge and Data Engineering, 4347(c), 1-1. https://doi.org/10.1109/tkde.2019.2962680

[18] Schäfer, F., Zeiselmair, C., \& Becker, J. (2019). 2018 IEEE International Conference on Technology Management, Operations and Decisions, ICTMOD 2018. 2018 IEEE International Conference on Technology Management, Operations and Decisions, ICTMOD 2018, 190-195.

[19] CELIK, U., \& BASARIR, C. (2017). The Prediction of Precious Metal Prices via Artificial Neural Network by Using RapidMiner. $\begin{array}{lll}\text { Alphanumeric Journal, } & \text { 5(1), }\end{array}$ https://doi.org/10.17093/alphanumeric.290381

[20] Lee, T., Singh, V. P., \& Cho, K. H. (2021). Deep Learning for Time Series. 107-131. https://doi.org/10.1007/978-3-030-64777-3_9

[21] Sezer, O. B., Gudelek, M. U., \& Ozbayoglu, A. M. (2020). Financial time series forecasting with deep learning: A systematic literature review: 2005-2019. Applied Soft Computing Journal, 90, 106181. https://doi.org/10.1016/j.asoc.2020.106181 